\title{
EFEKTIFITAS PENGELOLAAN KEPARIWISATAAN DI KABUPATEN POLEWALI MANDAR
}

\author{
Andi Ismawaty1), Hasanuddin ${ }^{2}$. Jinne ${ }^{3)}$ \\ 1Jurusan Ilmu Administrasi Negara, STISIP Bina Generasi Polewali \\ Email: andiismawaty@stisipbiges.ac.id \\ ${ }^{2}$ Jurusan Ilmu Administrasi Negara, STISIP Bina Generasi Polwwali \\ Email: hasanuddin@stisipbiges.ac.id \\ ${ }^{3}$ Mahasiswa Jurusan Ilmu Administrasi Negara, STISP Bina Generasi Polewali
}

\begin{abstract}
Tourism is the sector with the most potential to generate foreign exchange and the easiest to create jobs. In this context, economic activity will directly increase and have an impact both in improving the standard of living and welfare of the community and in supporting the increase in local revenue. The purpose of this study was to determine the readiness of the region in the management of tourism programs both for increased development and for increasing economic activity in the Polewali Mandar District. This study uses a descriptive-qualitative approach and the selection of informants by purposive sampling. The techniques of data collection and analysis are in stages, namely: data reduction, data presentation and conclusion drawing. This research uses a case study analysis strategy by taking cases in the tourism program that has been carried out. The results of the study indicate that tourism management still needs to be improved so that it can encourage economic activity in Polewali Mandar Regency.
\end{abstract}

Keyword: Effectiveness, Management, Tourism Programs

\begin{abstract}
ABSTRAK
Pariwisata merupakan sektor yang paling potensial mendatangkan devisa dan paling mudah menciptakan lapangan kerja. Dalam konteks ini aktivitas ekonomi secara langsung akan meningkat serta memberi dampak baik dalam meningkatkan taraf hidup dan kesejahteraan masyarakat maupun dalam menunjang peningkatan pendapatan asli daerah (PAD). Tujuan penelitian ini untuk mengetahui kesiapan daerah dalam pengelolaan program kepariwisataan baik bagi peningkatan pembangunan maupun bagi peningkatan aktivitas ekonomi masyarakat di Kabupaten Polewali Mandar. Penelitian ini menggunakan pendekatan deskriptif-kualitatif serta pemilihan informan secara purposive sampling. Adapun teknik pengolhan dan analisis data dengan tahapan yaitu: reduksi data, penyajian data dan penarikan kesimpulan. Penelitian ini menggunakan strategi analisis studi kasus dengan mengambil kasus-kasus pada program kepriwisataan yang telah dilksanakan. Hasil penelitian penunjukkan bahwa pengelolaan kepariwisataan masih perlu ditingkatkan sehingga dapat mendorong pengingkatan aktivitas ekonomi di Kabupaten Polewali Mandar.
\end{abstract}

Kata Kunci: Efektifitas, Pengelolaan, Program Kepariwisataan

\section{PENDAHULUAN}

Pariwisata saat ini merupakan salah satu penggerak ekonomi, yang dapat diandalkan dalam pertumbuhan ekonomi Indonesia, hal mana terbukti telah memperlihatkan capaian yang menggembirakan. Karena sektor pariwisata ini cukup menjanjikan sehingga diperlukan pengelolaan yang baik.

Pariwisata adalah perjalanan yang dilakukan untuk sementara waktu,yang 
selenggarakan dari suatu tempat lain dengan maksud dan bukan untuk berusaha (business) atau mencari nafkah di tempat yang dikunjuginya, tapi semata-mata untuk menikmati perjalanan bertamasya dan rekreasi atau untuk memenuhi keinginan yang beraneka ragam(Peranan sektor pariwisata dalam meningkatkan pendapatan asli daerah kota palopo ahmar, nurlinda, mustafa muhani, n.d.) (2012). Kepariwisataan menurut Undang-Undang Republik Indonesia Nomor 10 Tahun 2009 Tentang Kepariwisataan, adalah keseluruhan kegiatan yang terkait dengan pariwisata dan bersifat multidimensi serta multidisiplin yang muncul sebagai wujud kebutuhan setiap orang dan negara serta interaksi antara wisatawan dan masyarakat setempat, sesama wisatawan, Pemerintah, Pemerintah Daerah, dan pengusaha

Saat ini pariwisata telah menjadi salah satu industri gaya baru yang mampu menyediakan pertumbuhan ekonomi yang cepat dalam hal kesempatan kerja, pendapatan, taraf hidup dan dalam mengaktifkan sektor produksi lain di dalam negara penerima wisatawan(Salah Wahab, 2003) Karena sektor pariwisata ini cukup menjanjikan sehingga diperlukan pengelolaan yang baik. Dalam pengelolaan kepariwisataan, ada beberapa hal unik, antara lain harus menekankan nilai-nilai kelestarian lingkungan, nilai sosial, dan juga komunitas. Semuanya dikemas dalam sajian wisata yang bisa dinikmati oleh wisatawan.

Sejalan dengan hal ini berbagai program pemerintah terus dilakukan dalam rangka meningkatkan kinerja kepariwisataan Indonesia sebagai salah satu sektor andalan pembangunan nasional.

Penelitian terkait pengelolaan kepariwisataan telah dilakukan sebelumnya oleh Badarab dkk (Badarab, Trihayuningtyas, \& Suryadana, 2017) dengan hasil penelitian yang menunjukkan bahwa peningkatan kunjungan wisatawan ditentukan oleh aksesbilitas produk wisata dan profesionalitas sumber daya manusia dalam mengelola pengembangan destinasi wisatanya.

Penelitian lainnya dilakukan oleh Stephani (Walangitan, n.d.) (2014). Dalam penelitiannya menunjukkan keberhasilan pembangunan daerah juga ditentukan dan dikontribusi oleh faktor kebijakan pengembangan pariwisata di daerah tersebut.

Selain itu penelitian yang dilakukan oleh Alfaridho (2016) menunjukkan bahwa promosi merupakan salah satu cara dalam pengelolaan kepariwisataan karena langsung tertuju pada calon wisatawan maupun khalayak yang membutuhkan informasi pariwisata. Sehingga website merupakan sarana yang tepat karena sifatnya yang cepat dan mudah diakses.

Beberapa hasil penelitian diatas menunjukkan bahwa potensi kepariwisataan memang seyogyanya dikelola dengan baik, sehingga jika dikelola dengan baik akan sangat membantu bagi peningkatan perekonomian didaerah yang bersangkutan.

Untuk menarik wisatawan baik domestik dan asing, Kabupaten Polewali Mandar Provinsi Sulawesi Barat mengadakan berbagai program kepariwisataan yang dikemas dalam kegiatan Polewali Mandar Expo. Salah satu kegiatan yang menyedot pengunjung baik domestik maupun mancanegara adalah Polewali Mandar International Folk and Art Festival (PIFAF). Kegiatan ini merupakan salah satu kegiatan seni, budaya dan pariwisata yang bertaraf internasional dan masuk dalam Daftar 100 Calendar of Event 2019 Kementrian Pariwisata Republik Indonesia.

Kegiatan tahunan tersebut mendatangkan beberapa manfaat disamping peningkatan aktivitas ekonomi bagi kabupaten Polewali Mandar seperti terbukanya ruang interaksi dan komunikasi antara seniman tradisional Polewali Mandar dengan seniman tradisional negara lain, serta meningkatnya pemahaman generasi muda terhadap budaya bangsa asing yang dapat dijadikan menjadi filter dalam menangkal 
pengaruh negatifnya terhadap budaya bangsa Indonesia.

Meskipun demikian perlu dipertimbangan antara sarana dan prasarana yang ada didaerah dengan tingkat kedatangan wisatawan khususnya bila ada event. Lonjakan tingkat hunian dan ketresediaan rumah makan kadangkala tidak seimbang, sehinggadapat menimbulkan kesan bahwa daerah belum siap.

Karena pariwisata dalam hal ini merupakan suatu kegiatan yang secara langsung menyentuh dan melibatkan masyarakat, sehingga membawa berbagai dampak terhadap masyarakat setempat (Sosial, Pembangunan, Umbul, Kecamatan, \& Kabupaten, 2015) Dengan demikian adanya pengembangan dan peningkatan sarana dan prasarana sektor pariwisata akan meningkatkan pemerintah pandapatan asli daerahnya dan secara otomatis akan meningkatkan aktivitas ekonomi di dearah ini. Disamping itu hal tersebut berkaitan pula dengan pelayanan yang diberikan oleh pemerintah daerah. Bahwa pelayanan publik selalu dikaitkan dengan suatu kegiatan yang dilakukan oleh seseorang atau kelompok orang atau instansi tertentu untuk memberikan bantuan dan kemudahan kepada masyarakat dalam rangka mencapai tujuan tertentu (Nurdin, Indonesia, \& Makassar, 2019). Sehingga wisatawan yang datang dapat terlayani secara maksimal

Fenomena yang ada di Kabupaten Polewali Mandar dalam melayani kedatangan wisatawan apalagi pada setiap perhelatan besar seperti Polewali Mandar International Folk and Art Festival (PIFAF) ini adalah keterbatasan akomodasi dan sarana transportasi sehingga dibutuhkan evaluasi agar dapat ditingkatkan. Jumlah hotel sebanyak 25 dengan tingkat hunian sebesar 663 orang, jelas sangat kurang dibandingkan dengan jumlah pengunjung yang datang. Wisatawan dmanca negara yang berkunjung ke kabupaten Polewali Mandar pada tahun 2018 adalah sebanyak 719 orang dan wisatawan domestic adalah sebanyak
220.253 orang. Jumlah rumah makan adalah 151 unit dan 80 unit diantaranya berada di ibukota kabupaten. Sedangkan dari segi transportasi dalam hal ini adalah kondisi jalanan sepanjang 1.071,74 km, kondisi yang baik adalah sepanjang 552,86 km sisanya dalam kondisi sedang, rusak sedang dan rusak parah. Selain itu transportasi umum (taksi) atau tarnsportasi online belum tersedia.

Kekurangan dalam pelayanan seperti pada rumah makan yang rata-rata tidak memberikan tabel harga pada menunya. Bagi wisatawan manca negara hal ini merupakan satu hal yang sangat diperlukan. Bukan masalah berapa harga yang harus dibayar tetapi mengenai etika sebuah rumah makan dimana pengunjung seharusnya mengetahui terlebih dahulu berapa harga yang akan mereka pesan dan santap. Sehingga hal ini menimbulkan ketidaknyamanan bahkan menunjukkan bahwa sebenarnya daerah belum siap menjadi destinasi wisata.

Berdasarkan gambaran tersebut diatas yang membedakan penelitian ini dengan penelitian yang ada sebelumnya. Penelitian ini akan menganalisa kesiapan daerah dalam pengelolaan program kepariwisataan baik bagi peningkatan pembangunan maupun bagi peningkatan aktivitas ekonomi masyarakat melalui sarana dan prasarana yang ada.

\section{METODE}

Penelitian ini merupakan penelitian deskriptif dengan pendekatan kualitatif dengan pertimbangan bahwa fenomena yang muncul dalam kepariwisataan merupakan hal yang patut dipertimbangkan dalam penentuan kebijakan. Penentuan kebijakan sebagai hasil evaluasi dari berbagai fenomena yang ada menjadi kajian yang penting bagi pihak yang terlibat dalam proses tersebut.

Adapun data yang diperoleh adalah sesuai pengamatan dan peristiwa yang terjadi di lokasi penelitian dan sesuai dengan fokus penelitian. Sumber data lainnya 
diperoleh melalui dokumen-dokumen yang berkaitan dengan fokus penelitian. Selain itu teknik pengumpulan data adalah melalui wawancara, observasi dan dokumentasi.

Teknik analisa data menggunakan model Miles dan Huberman dalam Sugiyono(Sugiyono, 2007), yang mengemukakan bahwa aktifitas dalam analisis data kualitatif dilakukan secara interaktif dan berlangsung secara terus menerus sampai tuntas, sehingga datanya sudah jenuh. Dalam menganalisis data menggunakan tiga aktifitas yaitu: reduksi data, penyajian data, dan kesimpulan.

\section{HASIL DAN PEMBAHASAN}

\section{Kejelasan Pelaksanaan}

Hasil penelitian menunjukkan bahwa kejelasan tugas dan fungsi panitia yang telah dibentuk berjalan dengan baik. Begitupun pada saat panitia menjelaskan maksud dan tujuan diadakannya Polewali Internasional Folk and Art Festifal kepada seluruh peserta yang ikut didalam kegiatan ini.

Salah satu manfaat diadakannya kegiatan ini yakni terjadinya peningkatan ekonomi dengan adanya perputaran uang yang mencapi 12 milyar selama 7 (tujuh) hari pelaksanaan. Disamping itu terciptanya ruang interaksi dan komunikasi antara pihak investor dengan pihak pelaku usaha sehingga menjadikan iklim perdagangan yang kondusif. Selain itu terbukanya ruang promosi kepada pelaku usaha pariwisata maupun pelaku usaha lainnya termasuk pelaku usaha kecil dan menengah untuk mempromosikan dan memasarkan produk unggulannya sebagai manfaat pelaksanaan PIFAF.

Tabel 1. Kejelasan Pelaksanaan PIFAF

\begin{tabular}{ccc}
\hline & Jelas & Tidak \\
\hline Panitia & ya & \\
Tujuan & ya & \\
Manfaat & ya & \\
\hline
\end{tabular}

Sehingga dengan demikian maka dari segi kejelasan (tabel 1) dapat digambarkan bahwa kejelasan tujuan yang hendak dicapai dalam pelaksanaan PIFAF (Polewali Mandar International Folk and Art Festival) di Kabupaten Polewali Mandar sudah sesuai karena apa yang telah direncanakan dapat terlaksana dimana seluruh rangkaian kegiatannya berjalan dengan lancar dan efektif meskipun ada beberapa kendala yang dihadapi.

Hal yang menjadi perhatian para pemangku kepentingan adalah bagaimana mempertahankan roda ekonomi pasca kegiatan ini berlangsung. Jangan karena ada kegiatan sehingga ekonomi menggeliat namun setelah kegiatan semua kembali seperti sedia kala. Jadi pelaku ekonomi seperti pengusaha dan pedagang serta pemilik hotel dan rumah makan sepertinya harus berbenah dengan meningkatkan kualitas dan mutu layanannya agar menarik perhatian dan tetap dijadikan sebagai daerah tujuan wisata meskipun tidak ada event. Ini bertujuan agar membantu pemerintah daerah dalam meningkatkan pertumbuhan ekonomi serta pendapatan asli daerah (PAD) yang pada akhirnya berimbas pada pembangunan daerah.

\section{Sarana dan Prasarana}

Sarana dan Prasarana yang mendukung pelaksanaan kegiatan kepariwisataan apalagi dengan event internasional masih perlu mendapat perhatian dari pemerintah daerah. Hasil penelitian menunjukkan sebagai beikut (table 2).

Meskipun peserta dan timnya tidak ada yang dirugikan terkait keterbatasan sarana prasarana yang tersedia, namun bukan berarti tidak ada masalah. Begitu juga dengan wisatawan yang khusus datang untuk menyaksikan kegiatan ini. Hal ini penting untuk dievaluasi sebagai masukan untuk perencanaan di masa datang baik untuk kegiatan yang sama maupun kegiatan lainnya.

Tabel 2. Sarana Prasarana yang mendukung kegiatan kepariwsataan 


\begin{tabular}{cc}
\hline & Terpenuhi \\
\hline Akomodasi & ya \\
Konsumsi & ya \\
Transportasi & ya \\
\hline
\end{tabular}

Sumber : Hasil reduksi data

Data yang ada terkait sarana dan prasarana tersebut adalah hotel dan penginapan yang tersedia sebanyak 25 unit dengan jumlah tempat tidur sebanyak 405 buah. Jika event yang bertaraf internasional dengan jumlah peserta serta timnya bisa dibayangkan kesulitan yang terjadi dalam ketersediaan akomodasi tersebut. Belum lagi kualitasnya, karena dari 25 unit ini hanya 11 unit, namun hanya 2 unit hotel saja yang memenuhi standar internasional selebihnya adalah penginapan dan wisma.

Karena daerah ini merupakan salah satu destinasi wisata di Provinsi Sulawesi Barat, maka sebaiknya mengembangkan transportasi umum semacam Go Car atau Grab sehingga memudahkan para tamu atau pengunjung dalam berkeliling daerah ini. Hasil penelitian menunjukkan bahwa salah satu yang menjadi kendala dalam pengelolaan kepariwisataan di Kabupaten Polewali Mandar adalah keterbatasan angkutan umum. Sebagai ibu kota kabupaten yang kerap menjadi tempat penyelenggaraan evet internasional sudah saatnya memperhatikan dan membuat regulasi mengenai kemudahan transportasinya.

Disamping itu fasilitas rumah makan yang juga terbatas dengan jumlah sebanyak 80 unit rumah makan yang terdapat di dalam kota dengan berbagai tingkatan.

Grafik 1 menunjukkan jumlah kunjungan wisatawan ika dibandingkan dengan keterediaan fasilitas yang ada di Kabupaten Polewali Mandar dalam tiga tahun terakhir menunjukkan keterbatasan fasilitas baik secara standar nasional maupun internasional. Tahun 2019 sampai dengan bulan Agustus, jumlah kunjungan wisatawan manca negara adalah sejumlah 589 dan domestik sebanyak 450.968 orang. Hal ini menunjukkan adanya ketidakseimbangan antara jumlah kunjungan dengan fasilitas yang tersedia di Kabupaten Polewali Mandar baik secara jumlah maupun secara standar.
Grafik 1. Jumlah Kunjungan Wisatawan

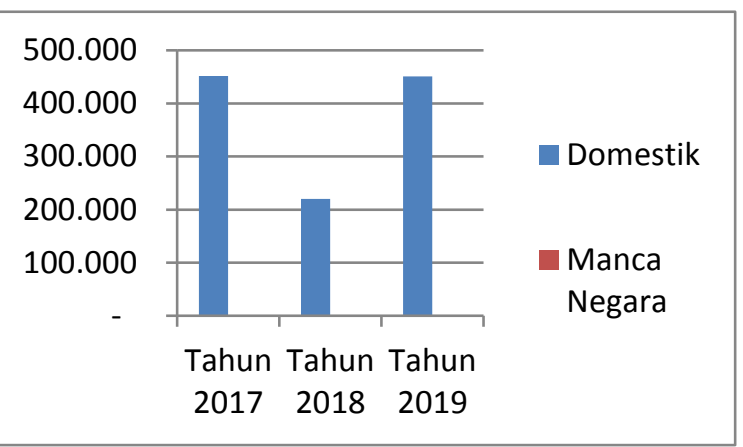

Sumber : Hasil reduksi

Disamping itu beberapa faktor yang menghambat dalam pengelolaan program kepariwisataan di Kabupaten Polewali Mandar adalah sebagian masyarakat tidak menerima kegiatan bertaraf intrnasional. meskipun jumlah yang kontra tidak begitu signifikan dalam mempengaruhi kebijkan dalam pelaksanaan kegiatan dan pengelolaan kepariwisataan baik yang telah dilaksnakan maumpun yang akan dilaksanakan di masa yang akan datang. Salah satu alasan masyarakat yang tidak mendukung kegiatan ini karena mereka menganggap budaya asing dapat mempengaruhi mental masyarakat lokal.

Keterbatasan dari sisi penganggaran merupakan kendala dalam pengelolaan program-program kepariwisataan ini, sehingga panitia pelaksana kewalahan mencari sponsor dan bantuan. Untuk kegiatan serupa dimasa akan datang seyogyanya memperhitungkan besarnya anggaran yang akan digunakan berdasarkan realisasi anggaran kegiatan sebelumnya.

\section{SIMPULAN DAN SARAN}

Keberhasilan pembangunan daerah sanat ditentukan oleh pengelolaan 
program-program pembangunan itu sendiri. Begitu juga di sektor pariwisata, bila dikelola dengan baik akan berdampak positif baik dari segi pemanfaatan potensi daerah, mengurangi pengangguran karena terbukanya lapangan kerja, lingkungan serta peningkatan ekonomi masyarakat, yang kesemuanya berdampak pula pada peningkatan Pendapatan Asli Daerah (PAD).

Kesiapan daerah dalam pengelolaan kepariwisataan di Kabupaten Polewali Mandar belum terlaksana secara maksimal, terlihat dari fasilitas sarana dan prasarana kepariwisataan yang masih dibawah standar baik secara kuantitas maupun kualitasnya. Selain itu keterbatasan dari segi penganggaran di sektor ini menjadi kendala dalam pengelolaan kepariwisataan maupun dalam penyelenggaraan program kepariwisataan. Padahal pada setiap event apalagi event yang bertaraf internasional mampu mendongkrak perputaran ekonomi selama berjalannya kegiatan. Pada kegiatan Polewali Internartional Folk and Art misalnya perputaran uang mecapai 12 milyar. Artinya, kegiatan semacam ini patut ditingkatkan pengelolaannya.

\section{Simpulan}

\section{REFERENSI}

Badarab, F., Trihayuningtyas, E., \& Suryadana, M. L. (2017). Strategi Pengembangan Destinasi Pariwisata di Kepulauan Togean Provinsi Sulawesi Tengah. 7(2), 97-112.

Nurdin, N. H., Indonesia, U., \& Makassar, T. (2019). Jurnal Ilmiah Paranata Edu Volume 1 No 1, Maret 2019 ISSN : 26566788 OPTIMALISASI PELAYANAN PUBLIK DALAM PERSPEKTIF NEW PUBLICK Jurnal Ilmiah Paranata Edu
Pengelolaan kepariwisataan di Kabupaten Polewali Mandar belum efektif jika dilihat dari aktivitas ekonomi masyarakat sebagai hasil pelaksanaan kegiatan yang berkaitan dengan sektor pariwisata. Dalam tiga tahun pelaksanaan event internasional yang diharapkan

mendatangkan investor di daerah ini belum berhasil, terlihat dari jumlah hotel yang berstandar masih sangat minim. Sehingga dapat dikatakan bahwa pemerintah daerah belum terlalu siap dengan kegiatan pariwisata bertaraf internasional.

\section{Saran}

Mengacu pada beberapa temuan penelitian, maka disarankan agar pemeintah daerah dapat berkolaborasi dan berkoordinasi dengan baik dengan seluruh stakeholder yang terlibat dalam sektor pariwisata ini, karena hasil industri pariwisata dapat berkontribusi pada pendapatan asli daerah (PAD) dan peningkatan ekonomi masyarakat, sehingga dapat mempengaruhi peningkatan pembangunan baik secara lokal maupun nasional.

Volume 1 No 1 , Maret 2019 ISSN : 26566788. 1(1), 1-13.

Peranan sektor pariwisata dalam meningkatkan pendapatan asli daerah kota palopo ahmar, nurlinda, mustafa muhani. (n.d.).

Salah Wahab. (2003). No TitleManajamen Kepariwisataan. Jakarta: Pradnya Paramitha.

Sosial, D., Pembangunan, E., Umbul, P., Kecamatan, S., \& Kabupaten, B. (2015). Economics Development Analysis Journal. 
$4(4), 443-451$.

Sugiyono. (2007). No Title Metode Penelitian Kualitatif Kuantitatif dan R\&D. Bandung: Alfabeta.

Walangitan, S. F. (n.d.). EFEKTIVITAS KEBIJAKAN PENGEMBANGAN

Alfaridho etc, (2016), Efektivitas Website Pemerintah Kabupaten Karanganyar Sebagai Sumber Informasi Kepariwisataan Remaja, Jurnal Transformasi Vol 11, hal 80-85
PARIWISATA DALAM MENUNJANG PEMBANGUNAN DAERAH DI KABUPATEN TOLITOLI PROVINSI SULAWESI TENGAH. Stephani F Walangitan. 